\title{
Carbamoyl Derivatives of a Pyridine-Based Tetraamine
}

\author{
Anvarhusen K. Bilakhiya ${ }^{\mathrm{a}}$, Frank W. Heinemann ${ }^{\mathrm{b}}$, and Andreas Grohmann ${ }^{\mathrm{a}}$ \\ a Technische Universität Berlin, Institut für Chemie, Sekretariat C2, Straße des 17. Juni 135, \\ D-10623 Berlin, Germany \\ ${ }^{\mathrm{b}}$ Universität Erlangen-Nürnberg, Institut für Anorganische Chemie, Egerlandstraße 1, \\ D-91058 Erlangen, Germany
}

Reprint requests to Prof. A. Grohmann. Fax: +49-30-31422935.

E-mail: andreas.grohmann@ @chem.tu-berlin.de

Z. Naturforsch. 2007, 62b, 519-522; received October 10, 2006

Dedicated to Professor Ulrich Zenneck on the occasion of his $60^{\text {th }}$ birthday

\begin{abstract}
The reaction of four equivalents of phenyl or tert-butyl isocyanate with the pyridine-derived tetraamine 2,6- $\mathrm{C}_{5} \mathrm{H}_{3} \mathrm{~N}\left[\mathrm{CMe}\left(\mathrm{CH}_{2} \mathrm{NH}_{2}\right)_{2}\right]_{2}$ in toluene gives high yields of the quadruply ureido substituted products $2,6-\mathrm{C}_{5} \mathrm{H}_{3} \mathrm{~N}\left[\mathrm{CMe}\left(\mathrm{CH}_{2} \mathrm{R}\right)_{2}\right]_{2}\left[\mathrm{R}=-\mathrm{NH}(\mathrm{CO}) \mathrm{NHPh}\right.$ and $-\mathrm{NH}(\mathrm{CO}) \mathrm{NH}^{t} \mathrm{Bu}$. Full spectroscopic data for both compounds are given. A single crystal X-ray structure determination of the phenyl derivative reveals an intricate network of both intra- and intermolecular hydrogen bonds involving the $\mathrm{C}=\mathrm{O}$ and both $\mathrm{NH}$ functionalities in all ureido groups.
\end{abstract}

Key words: Tetrapodal Pentadentate Ligand, Urea, Chelates, Hydrogen Bonding

\section{Introduction}

Urea functionalities in ligands have gained prominence recently. $\mathrm{N}, \mathrm{N}^{\prime}$-dialkyl ureas are readily transformed into chelating diphosphanes of the type $\mathrm{R}_{2} \mathrm{P}-\mathrm{NR}^{\prime}(\mathrm{C}=\mathrm{O}) \mathrm{NR}^{\prime}-\mathrm{PR}_{2}$, through the reaction with chlorodiorganyl phosphanes in the presence of a base such as triethylamine [1]. The substituents on both the phosphorus and nitrogen atoms may be varied broadly, and thus used to tune the steric and electronic properties of the ligands. Unmodified ureas are poor ligands for transition metals, and coordination is most often through the carbonyl oxygen atom [2]. The lone pair on the nitrogen atom is all but unavailable, as it is strongly delocalised into the $\mathrm{N}-\left(s p^{2}-\mathrm{C}\right)$ bond, which thus gains partial double bond character. Deprotonation of the nitrogen atom, however, makes a lone pair available for complex formation. Following this rationale, Borovik recently prepared chelate complexes of iron, cobalt and manganese in which a tripodal tetradentate ligand (a triamido amine) coordinates to the metal centre, to give trigonal pyramidal complexes. A fifth coordination site, encircled by ureido $\mathrm{NH}$ groups set up for hydrogen bonding interactions, is available on the metal ion to give complexes of overall trigonal bipyramidal geometry, and has been used to stabilise oxygenfunctional ligands in a manner reminiscent of metalloenzyme function [3].

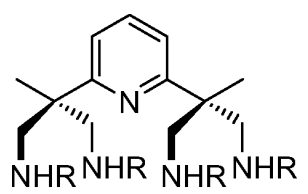

1

We recently introduced the pyridine-derived tetraamine imine 2,6- $\mathrm{C}_{5} \mathrm{H}_{3} \mathrm{~N}\left[\mathrm{CMe}\left(\mathrm{CH}_{2} \mathrm{NH}_{2}\right)_{2}\right]_{2}(\mathbf{1}, \mathrm{R}=\mathrm{H})$ as a highly symmetrical ligand of even higher denticity. Our study of such tetrapodal pentadentate ligands is motivated by the recognition that they provide a single "labile" coordination site in complexes of overall octahedral symmetry [4]. It is in this context that we are preparing derivatives of the type 2,6$\mathrm{C}_{5} \mathrm{H}_{3} \mathrm{~N}\left[\mathrm{CMe}\left(\mathrm{CH}_{2} \mathrm{NHR}\right)_{2}\right]_{2}$ [5]. The present contribution details the preparation of derivatives in which $\mathrm{R}$ is a carbamoyl residue derived from an organyl isocyanate.

\section{Results and Discussion}

The transformation of the primary amine functionalities into ureido groups relies on the reaction with organyl isocyanates, $\mathrm{R}-\mathrm{N}=\mathrm{C}=\mathrm{O}[6]$. Phenyl and tertbutyl isocyanate were employed, and compounds 2 and $\mathbf{3}$ were prepared in this manner. For a polyfunctional molecule such as $\mathbf{1}(\mathrm{R}=\mathrm{H})$, the choice of solvent 


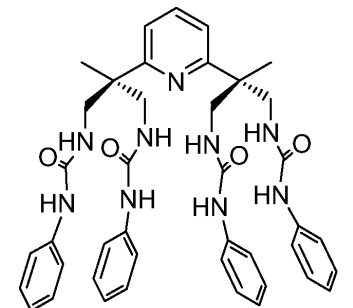

2

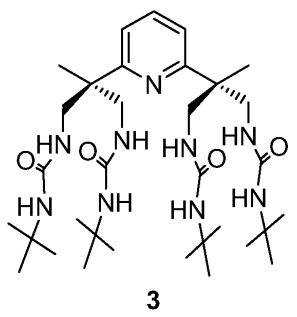

appears critical in order to effect complete derivatisation. The highest yields of tetrasubstituted product ( $\mathrm{ca}$. $90 \%$ ) were obtained when the tetraamine was reacted with the isocyanates at r.t. in toluene. Yields are similarly high in chloroform, but the time required for conversion is about twice as long (15 vs. $30 \mathrm{~h})$. The anhydrous and acid-free tetraamine may be obtained as a yellowish oil from its hydrogen bromide adduct (storage form, contains 4 eq. $\mathrm{HBr}$; $c f$. Experimental Section) by treatment of a suspension in methanol with a slightly greater than stoichiometric amount of sodium methoxide, evaporation of the solvent, extraction of the residue with methylene chloride to remove sodium bromide and finally, evaporation of the filtrate. Care must be taken to remove all hydrogen bromide, which otherwise interferes with the introduction of the carbamoyl groups, to give partially substituted products. Whether or not this property may be used to effect partial substitution of the tetraamine in a regioselective manner is a question currently under investigation [5].

The IR spectra of $\mathbf{2}$ and $\mathbf{3}$ are characterised by strong bands ("amide I" around $1650 \mathrm{~cm}^{-1}$ and "amide II" around $1560 \mathrm{~cm}^{-1}$ ) due to the $\mathrm{C}=\mathrm{O}$ stretching and $\mathrm{N}-\mathrm{H}$ deformation/C-N stretching vibrations, respectively [7]. In the ${ }^{1} \mathrm{H}$ NMR spectrum of 2 , the $\mathrm{Ph}-\mathrm{NH}$ protons show at lowest field $(\delta=8.49 \mathrm{ppm})$, separated by more than $2 \mathrm{ppm}$ from the other $\mathrm{NH}$ signal $(\delta=6.26 \mathrm{ppm})$, which has triplet multiplicity due to the neighbouring methylene groups. These methylene groups give rise to the expected AB pattern (the geminal protons being diastereotopic), with an additional splitting into doublets imposed by the neighbouring $\mathrm{NH}$ protons. This splitting is removed upon $\mathrm{D}_{2} \mathrm{O}$ exchange, to give the simple "doublet of doublets" pattern. Similar spectra are expected for metal complexes of the deprotonated ureido ligands. The pyridine protons show a first-order $\mathrm{AB}_{2}$ pattern (triplet/doublet), and the phenyl protons give rise to a set of doublet (ortho, overlayed with the pyridine doublet), triplet (meta) and triplet (para); the latter multiplicities also collapse upon $\mathrm{D}_{2} \mathrm{O}$ exchange, to give two broad singlets for
Table 1. Hydrogen bond parameters for 2 (D: donor; A: acceptor; distances $d$ in $\AA$, angles in ${ }^{\circ}$; standard deviations in parentheses; ' and " designate symmetry-equivalent atoms).

\begin{tabular}{|c|c|c|c|c|}
\hline$\overline{\mathrm{D}-\mathrm{H} \cdots \mathrm{A}}$ & $d(\mathrm{D}-\mathrm{H})$ & $d(\mathrm{H} \cdots \mathrm{A})$ & $d(\mathrm{D} \cdots \mathrm{A})$ & $\angle(\mathrm{DHA})$ \\
\hline N12-H12N‥O40" & $0.90(3)$ & $2.04(3)$ & $2.869(3)$ & $153(2)$ \\
\hline N13-H13N…O30' & $0.86(3)$ & $2.03(3)$ & $2.843(3)$ & $157(3)$ \\
\hline $\mathrm{N} 13-\mathrm{H} 13 \mathrm{~N} \cdots \mathrm{N} 11$ & $0.86(3)$ & 2.53(3) & $2.953(2)$ & 111(2) \\
\hline $\mathrm{N} 30-\mathrm{H} 30 \mathrm{~N} \cdots \mathrm{O} 40 "$ & $0.89(3)$ & $2.09(3)$ & $2.879(3)$ & $148(2)$ \\
\hline N40-H40N …O30' & $0.88(3)$ & $2.10(3)$ & $2.887(3)$ & $148(2)$ \\
\hline
\end{tabular}

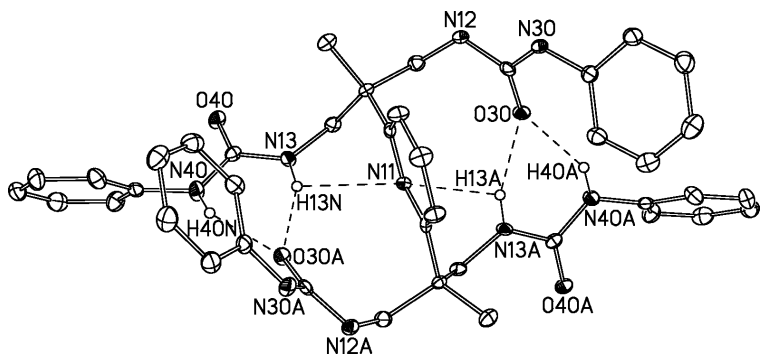

Fig. 1. Molecular structure of $\mathbf{2}$ (methylene chloride solvate molecules not shown; only $\mathrm{H}$ atoms involved in intramolecular hydrogen bonding are shown).

the ortho/meta and para protons, respectively. All signals have the correct integrated intensities. Apart from the obvious differences reflecting different molecular structures, the ${ }^{1} \mathrm{H}$ NMR spectrum of the tert-butyl derivative $\mathbf{3}$ has two closely spaced signals (overlayed singlet and doublet) for the $8 \mathrm{NH}$ protons around $5.67 \mathrm{ppm}$. In the mass spectrum of $\mathbf{2}$ (field desorption), there are four prominent peaks $\left(\mathrm{m} / z=727[\mathrm{M}]^{+}, 609\right.$, $490,371)$, each separated by 119 mass units from the next, corresponding to sequential loss of three PhNCO fragments. Other prominent signals are $m / z=119$, as expected, and $m / z=212[\mathrm{PhN}(\mathrm{CO}) \mathrm{NPh}]^{+}$. The mass spectrum of $\mathbf{3}$ is overall similar.

In the solid-state structure of 2 (Fig. 1), the $C_{2}$ symmetrical molecule adopts a conformation with intramolecular hydrogen bond contacts as shown, which also involve the pyridine nitrogen atom (N11). Stacking in three dimensions is by $\pi-\pi$ interactions between symmetry-equivalent phenyl rings (the distance between the ring centroids is 4.18(4) $\AA$ ) [8], in concert with intermolecular hydrogen bonds: The urea oxygen atoms $\mathrm{C}=O(40)$ receive two such bonds in pincerlike fashion from the $\mathrm{R}-\mathrm{NH}-(\mathrm{CO})-\mathrm{N} H \mathrm{R}$ portion of an adjacent molecule (H12, H30; Fig. 2 and Table 1). This feature has precedent, and is being used in crystal engineering [9]. Other geometrical parameters have been deposited ( $c f$. Experimental Section). Hydrogen bonding in the solid may also be inferred from the IR spectrum (KBr disk), as only associated (hydrogen- 


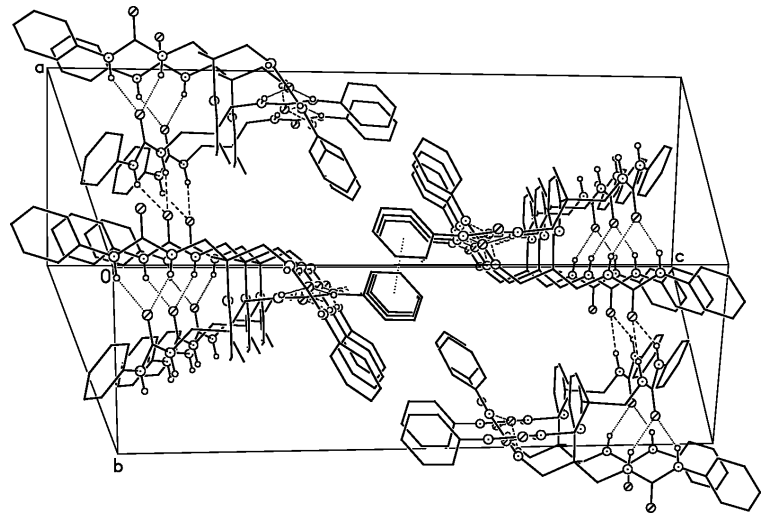

Fig. 2. Unit cell view of $2\left(\mathrm{CH}_{2} \mathrm{Cl}_{2}\right.$ solvate molecules removed), showing intermolecular (broken lines) and intramolecular hydrogen bonds (dotted lines), as well as $\pi$ - $\pi$ stacked phenyl rings (dotted lines).

bonded) ureas have bands due to the $\mathrm{N}-\mathrm{H}$ stretching vibration at $3400-3360 \mathrm{~cm}^{-1}$ and the carbonyl stretching vibration at about $1635 \mathrm{~cm}^{-1}$ (values for ureas with no hydrogen bonding: $3465-3435$ and $c a .1695 \mathrm{~cm}^{-1}$, respectively) [7]. The values observed for 2 are 3351 and $1651 \mathrm{~cm}^{-1}$, respectively.

\section{Conclusion}

All four primary amine functionalities in 2,6$\mathrm{C}_{5} \mathrm{H}_{3} \mathrm{~N}\left[\mathrm{CMe}\left(\mathrm{CH}_{2} \mathrm{NH}_{2}\right)_{2}\right]_{2}$ may be transformed into ureido groups by the reaction with isocyanates under suitable conditions. While the acidity difference between the two sets of $\mathrm{NH}$ protons in the products is quite small, it is expected to increase in the presence of suitable metal ions, as preferential deprotonation of the "inner" $\mathrm{NH}$ protons leading to an $\mathrm{N}\left(\mathrm{N}^{-}\right)_{5}$ donor set would enable the formation of square-pyramidally coordinated chelate complexes with stereochemically favoured six-membered rings. Such studies are currently in progress.

\section{Experimental Section}

The reactions were carried out at r.t. in dried solvents under an atmosphere of dry dinitrogen (Schlenk technique). The tetraamino imine ligand "pyN 4 " $(\mathbf{1}, \mathrm{R}=\mathrm{H})$ was used as the hydrogen bromide methanol adduct, prepared by literature methods [10]. Phenyl isocyanate and tert-butyl isocyanate were purchased from Fluka or Aldrich and used without further purification. IR spectra of solids were measured using $\mathrm{KBr}$ disks. Spectroscopic data were obtained using the following instruments: IR spectroscopy: PerkinElmer 1600 FT IR and 16PC FT IR; mass spectrometry: Var- ian MAT 212 and Jeol JMS 700; NMR spectroscopy: Jeol FT-NMR JNM-EX 270, Lambda LA 400 und ALPHA 500. Elemental analyses were carried out using Carlo Erba EA 1106 and 1108 analysers.

2,6- $\mathrm{C}_{5} \mathrm{H}_{3} \mathrm{~N}\left[\mathrm{CMe}\left(\mathrm{CH}_{2} \mathrm{NHR}\right)_{2}\right]_{2} ; \mathrm{R}=(\mathrm{CO}) \mathrm{NHPh}:$ 1-Phenyl-3-(3-(3-phenyl-ureido)-2-\{6-[2-(3-phenyl-ureido)-1-(3phenyl-ureidomethyl)-1-methyl-ethyl]-pyridin-2-yl)-2-methyl-propyl)-urea, $2 ; R=(C O) N H^{t} B u$ : 1-tert-Butyl-3-(3-(3tert-butyl-ureido)-2-\{6-[2-(3-tert-butyl-ureido)-1-(3-tertbutyl-ureidomethyl)-methyl)-1-methyl-ethyl]-pyridin-2-yl\}2-methyl-propyl)-urea (3)

Both compounds were prepared by similar methods. A stirred suspension of $\mathrm{pyN}_{4} \cdot 4 \mathrm{HBr} \cdot \mathrm{MeOH}(1.5 \mathrm{~g}, 2.5 \mathrm{mmol})$ was neutralised with $\mathrm{NaOMe}(0.5 \mathrm{M}$ solution; $20 \mathrm{~mL}$, $10 \mathrm{mmol}$ ), to give a clear solution within $1 \mathrm{~h}$. This was taken to dryness, the residue stirred with $\mathrm{CH}_{2} \mathrm{Cl}_{2}(30 \mathrm{~mL})$ for $1 \mathrm{~h}$, and the suspension filtered via cannula to remove solid $\mathrm{NaBr}$. Evaporation of the filtrate left the pure anhydrous polyamine as a yellowish oil. This was dissolved in toluene $(30 \mathrm{~mL})$, and to the solution was added dropwise at $\mathrm{r}$.t. the isocyanate (2: PhNCO, $1.22 \mathrm{~mL}, 11.3 \mathrm{mmol} ; 3:{ }^{t} \mathrm{BuNCO}$, $1.28 \mathrm{~mL}, 11.3 \mathrm{mmol})$ dissolved in toluene $(20 \mathrm{~mL})$. The solution was then set aside at r.t. and stirred for $16 \mathrm{~h}$. In order to obtain the phenyl derivative 2 , the solution was reduced in volume; diethyl ether $(50 \mathrm{~mL})$ was then added to produce a white precipitate, which was filtered off, washed with diethyl ether $(3 \times 20 \mathrm{~mL})$, dried in vacuo, and recrystallised from $\mathrm{MeOH}$. (Recrystallisation from $\mathrm{CH}_{2} \mathrm{Cl}_{2}$ provided single crystals suitable for $\mathrm{X}$-ray structure analysis.) Yield of 2: $1.6 \mathrm{~g}, 2.2 \mathrm{mmol}(88 \%) .3$ was obtained from the reaction solution by evaporation to dryness and quick washing with a small amount of diethyl ether. (Solvents for recrystallisation were methanol or diethyl ether.) Chloroform may be used instead of toluene as the reaction solvent, but a reaction time of about $30 \mathrm{~h}$ is required for complete conversion. Yield of 3: $1.5 \mathrm{~g}, 2.3 \mathrm{mmol}(92 \%)$. Data for 2: Elemental analysis: $\mathrm{C}_{41} \mathrm{H}_{45} \mathrm{~N}_{9} \mathrm{O}_{4}$ (727.85): calcd. C 67.66, H 6.23, N 17.32; found C 67.22, H 6.76, N 17.74. - ${ }^{1} \mathrm{H}$ NMR ([D $]$ DMSO, r.t.): $\delta=8.49$ (s, $4 \mathrm{H}, \mathrm{C}(=\mathrm{O}) \mathrm{NH}-\mathrm{Ph}), 7.74$ (t, $\left.{ }^{3} J_{\mathrm{H}, \mathrm{H}}=7.8 \mathrm{~Hz}, 1 \mathrm{H}, \mathrm{py}-\mathrm{H}^{4}\right), 7.29-7.11(\mathrm{~m}, 2+8+8 \mathrm{H}$, py$\left.\mathrm{H}^{3 / 5}, \mathrm{Ph}-\mathrm{H}^{2 / 6}, \mathrm{Ph}-\mathrm{H}^{3 / 5}\right), 6.85\left(\mathrm{t},{ }^{3} J_{\mathrm{H}, \mathrm{H}}=7.2 \mathrm{~Hz}, 4 \mathrm{H}, \mathrm{Ph}-\right.$ $\left.\mathrm{H}^{4}\right), 6.26\left(\mathrm{t},{ }^{3} J_{\mathrm{H}, \mathrm{H}}=5.9 \mathrm{~Hz}, 4 \mathrm{H}, \mathrm{CH}_{2} \mathrm{NHC}(=\mathrm{O})\right), 3.67-3.60$ (A part of AB spin system, "dd", ${ }^{2} J_{\mathrm{H}, \mathrm{H}} /{ }^{3} J_{\mathrm{H}, \mathrm{H}}=13.5 / 6.2 \mathrm{~Hz}$, $4 \mathrm{H}, \mathrm{CH} H$ ), $3.52-3.44$ (B part of AB spin system, "dd", $\left.{ }^{2} J_{\mathrm{H}, \mathrm{H}} /{ }^{3} J_{\mathrm{H}, \mathrm{H}}=13.3 / 6.2 \mathrm{~Hz}, 4 \mathrm{H}, \mathrm{CH}\right), 1.31\left(\mathrm{~s}, 6 \mathrm{H}, \mathrm{CH}_{3}\right)$; $+\mathrm{D}_{2} \mathrm{O}$ (selected signals): $7.67\left(\mathrm{t},{ }^{3} J_{\mathrm{H}, \mathrm{H}}=7.7 / 7.5 \mathrm{~Hz}, 1 \mathrm{H}\right.$, py$\left.\mathrm{H}^{4}\right), 7.22\left(\mathrm{~d},{ }^{3} J_{\mathrm{H}, \mathrm{H}}=7.8 \mathrm{~Hz}, 2 \mathrm{H}, \mathrm{py}-\mathrm{H}^{3 / 5}\right), 7.09(\mathrm{br}, 16 \mathrm{H}$, $\mathrm{Ph}-\mathrm{H}^{2 / 6}, \mathrm{Ph}-\mathrm{H}^{3 / 5}$ ), 6.84 (br, $4 \mathrm{H}, \mathrm{Ph}-\mathrm{H}^{4}$ ), $3.67-3.36$ (AB, $\left.2 \mathrm{~d},{ }^{2} J_{\mathrm{H}, \mathrm{H}}=13.1 / 13.4 \mathrm{~Hz}\right) .-{ }^{13} \mathrm{C}\left\{{ }^{1} \mathrm{H}\right\}$ NMR $\left(\left[\mathrm{D}_{6}\right] \mathrm{DMSO}\right.$, r. t.): $\delta=162.35$ (py-C2/6), $155.58(-C(=\mathrm{O})-), 140.17$ (Ph-C1), 137.09 (py-C4), 128.60 (Ph-C3/5), 128.62 (Ph-C4), 
121.21 (py-C3/5), 117.95 (Ph-C2/6), $46.67\left(-\mathrm{CH}_{2}-\right), 45.68$ (\rangle $\mathrm{C}\langle), 20.65\left(\mathrm{CH}_{3}\right) .-\mathrm{MS}(\mathrm{FD}): \mathrm{m} / z(\%)=609(100), 490$ (75), $727[\mathrm{M}]^{+}(40) .-\mathrm{IR}(\mathrm{KBr}): v=3351 \mathrm{~cm}^{-1}$ (NH str), 2959, 1651 (C=O/amide I), 1598, 1556 (amide II), 1498, 1441, 1312, 1261, 1096, 804.

Data for 3: Elemental analysis: $\mathrm{C}_{33} \mathrm{H}_{61} \mathrm{~N}_{9} \mathrm{O}_{4}$ (647.91): calcd. C 61.18, H 9.49, N 19.46; found C 60.86, H 9.58, N 18.95. $-{ }^{1} \mathrm{H}$ NMR ([D 6$]$ DMSO, r.t.): $\delta=7.60\left(\mathrm{t},{ }^{3} J_{\mathrm{H}, \mathrm{H}}=\right.$ $7.8 \mathrm{~Hz}, 1 \mathrm{H}$, py-H $\left.\mathrm{H}^{4}\right), 7.07\left(\mathrm{~d},{ }^{3} J_{H, H}=7.8 \mathrm{~Hz}, 2 \mathrm{H}\right.$, py- $\left.\mathrm{H}^{3 / 5}\right), 5.68\left(\mathrm{~s}, 4 \mathrm{H}, \mathrm{C}(=\mathrm{O}) \mathrm{NH}_{-}{ }^{t} \mathrm{Bu}\right), 5.66\left(\mathrm{t},{ }^{3} J_{\mathrm{H}, \mathrm{H}}=\right.$ $6.0 \mathrm{~Hz}, 4 \mathrm{H}, \mathrm{CH}_{2} \mathrm{NHC}(=\mathrm{O})$ ), 3.47-3.40 (A part of $\mathrm{AB}$ spin system, "dd", ${ }^{2} J_{\mathrm{H}, \mathrm{H}} /{ }^{3} J_{\mathrm{H}, \mathrm{H}}=13.1 / 6.2 \mathrm{~Hz}, 4 \mathrm{H}, \mathrm{CH} H$ ), $3.22-3.15$ (B part of AB spin system, "dd", ${ }^{2} J_{\mathrm{H}, \mathrm{H}}{ }^{3} J_{\mathrm{H}, \mathrm{H}}=$ 13.3/6.2 Hz, $4 \mathrm{H}, \mathrm{CH} H), 1.18$ (s, $\left.6 \mathrm{H}, \mathrm{CCH}_{3}\right), 1.12$ (s, $36 \mathrm{H}$, $\left.\mathrm{C}\left(\mathrm{CH}_{3}\right)_{3}\right) ;+\mathrm{D}_{2} \mathrm{O}$ (selected signals): $3.46-3.11(\mathrm{AB}, 2 \mathrm{~d}$, $\left.{ }^{2} J_{\mathrm{H}, \mathrm{H}}=13.2 / 13.3 \mathrm{~Hz}\right) .-{ }^{13} \mathrm{C}\left\{{ }^{1} \mathrm{H}\right\} \mathrm{NMR}$ ([D 6$]$ DMSO, r. t.): $\delta=162.12$ (py-C2/6), $157.60(-C(=\mathrm{O})-), 136.31$ (py-C4), 118.59 (py-C3/5), $48.85\left(-\mathrm{CH}_{2}-\right), 46.87\left(\mathrm{C}_{\left.\left(\mathrm{CH}_{3}\right)_{3}\right), 45.79}\right.$ $\left(-\mathrm{CCH}_{3}\right), 29.27\left(\mathrm{C}\left(\mathrm{CH}_{3}\right)_{3}\right), 20.10\left(-\mathrm{CCH}_{3}\right) .-\mathrm{MS}(\mathrm{FD})$ : $\mathrm{m} / \mathrm{z}(\%)=648[\mathrm{M}]^{+}(100), 519(20) .-\mathrm{IR}(\mathrm{KBr}): v=$ $3358 \mathrm{~cm}^{-1}$ (NH str), 2965, 2927, 2869, 1644 (C=O/amide I), 1557 (amide II), 1452, 1391, 1362, 1272, 1214, 814, 659.

\section{X-Ray crystallography}

Crystal data for compound 2 (methylene chloride solvate): $\mathrm{C}_{41} \mathrm{H}_{45} \mathrm{~N}_{9} \mathrm{O}_{4} \cdot 2 \mathrm{CH}_{2} \mathrm{Cl}_{2}\left(\mathrm{C}_{43} \mathrm{H}_{49} \mathrm{Cl}_{4} \mathrm{~N}_{9} \mathrm{O}_{4}\right), M=$ $897.71 \mathrm{~g} \mathrm{~mol}^{-1}$, colourless block, $0.38 \times 0.21 \times 0.20 \mathrm{~mm}^{3}$, monoclinic, space group $C 2 / c, a=14.6605(3), b=$ $10.7108(2), c=28.5208(6) \AA, \beta=102.496(2)^{\circ}, V=$
4372.4(2) $\AA^{3}, Z=4, \rho_{\text {calcd. }}=1.364 \mathrm{~g} \mathrm{~cm}^{-3}, T=100(2) \mathrm{K}$, $\mu=0.324 \mathrm{~mm}^{-1}, F(000)=1880 \mathrm{e}$, Nonius KappaCCD, $\operatorname{Mo} K_{\alpha}, \lambda=0.71073 \AA$, graphite monochromator, semiempirical absorption correction from equivalent reflections, $T_{\min } / T_{\max }=0.938 / 0.994, \phi$ - and $\omega$-rotations $\left(1.1^{\circ}, 13 \mathrm{sec}\right.$ per frame); 24481 reflections collected $\left(6.8 \leq 2 \Theta \leq 54.0^{\circ}\right)$, 4619 independent reflections $(R$ (int $)=0.0784), 2576$ "observed" $(I \geq 2 \sigma(I)), R 1=0.0540(I \geq 2 \sigma(I)), w R 2=0.1139$ (all data), number of refined parameters $355, \mathrm{GOF}=0.973$, max./min. residual electron density $0.246 /-0.324$ e $\AA^{-3}$. Structure solution by Direct Methods, full-matrix leastsquares refinement on $F^{2}$ using SHELXTL NT 5.10 (Bruker AXS, 1998). The molecule lies on a crystallographic twofold axis through $\mathrm{N} 11$ and $\mathrm{C} 13$, the pyridine $\mathrm{N}$ and $\mathrm{C} 4$ atoms. The solvate contains two equivalents of disordered $\mathrm{CH}_{2} \mathrm{Cl}_{2}$ per formula unit. Treatment of hydrogen atoms: The positions of all $\mathrm{H}$ atoms were determined from difference Fourier syntheses. The positional parameters were refined while a common isotropic displacement parameter was kept fixed during refinement.

CCDC 266761 contains the supplementary crystallographic data for this paper. These data can be obtained free of charge from The Cambridge Crystallographic Data Centre via www.ccdc.cam.ac.uk/data_request/cif.

\section{Acknowledgement}

Financial support of this work by the Deutsche Forschungsgemeinschaft (SPP 1118) is gratefully acknowledged.
[1] A. M.Z. Slawin, M. Wainwright, J.D. Woollins, J. Chem. Soc., Dalton Trans. 2001, 2724.

[2] A. Kircheiss, U. Pretsch, U. Borth, Z. Chem. 1980, 20, 349.

[3] A. S. Borovik, Acc. Chem. Res. 2005, 38, 54.

[4] A. Grohmann, Adv. Inorg. Chem. 2004, 56, 179.

[5] J. Pitarch López, F. W. Heinemann, A. Grohmann, Z. Naturforsch. 2004, 59b, 1600.

[6] S. Braese, S. Dahmen, M. Pfefferkorn, J. Combinatorial Chem. 2000, 2, 710.
[7] G. Socrates, Infrared Characteristic Group Frequencies, 2nd ed., Wiley, Chichester 1994.

[8] C. Janiak, J. Chem. Soc., Dalton Trans. 2000, 3885.

[9] R. Custelcean, M. G. Gorbunova, P. V. Bonnesen, Chem. Eur. J. 2005, 11, 1459.

[10] S. Schmidt, L. Omnès, F. W. Heinemann, J. Kuhnigk, C. Krüger, A. Grohmann, Z. Naturforsch. 1998, 53b, 946. 